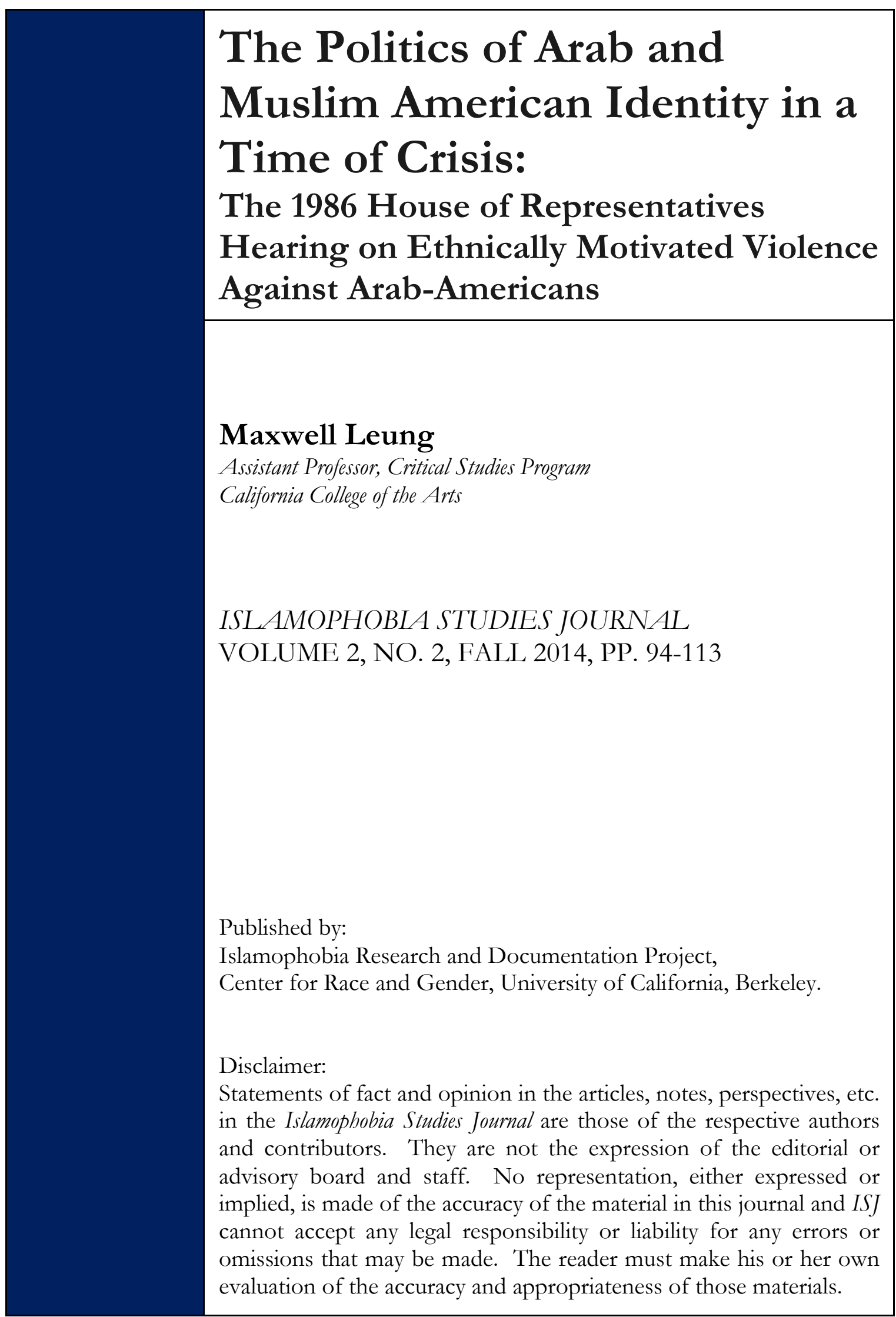




\title{
The Politics of Arab and Muslim American Identity in a Time of Crisis: The 1986 House of Representatives Hearing on Ethnically Motivated Violence Against Arab-Americans
}

\author{
Maxwell Leung \\ Assistant Profressor, Critical Studies Program \\ California College of the Arts
}

"I think I can say that Arab individuals or those supporting of Arab points of view have come within the zone of danger - targeting by a group as yet to be fully identified and brought to justice."

- William H. Webster, Director, Federal Bureau of Investigation, commenting on the murder of Alex Odeh and the rise of anti-Arab violence (December 11, 1985) ${ }^{81}$

"There is no such thing as a neutral subject. We are all inevitably someone's adversary." - Michel Foucault, Society Must Be Defended (2003)

\section{INTRODUCTION}

On July 16, 1986, a hearing on "Ethnically Motivated Violence Against ArabAmericans" was convened by the Subcommittee on Criminal Justice of the Committee of the Judiciary of the U.S. House of Representatives. This historic event was one of seven important hearings held in the five-year legislative history of the Hate Crime Statistics Act. ${ }^{82}$

\footnotetext{
81 See Philip Shenon, "F.B.I Chief Warns Arabs of Danger," New York Times, December 11, 1985, accessed November 24, 2014, http://www.nytimes.com/1985/12/11/us/fbi-chief-warns-arabs-of-danger.html. 82 Signed into law by President George Bush, Sr. on April 23, 1990, the Hate Crime Statistics Act (PL 101-275) is fundamentally a law designed to count the number of hate crimes committed annually. The HCSA defines "predicate crimes," or crimes where the question of bias can be applied to race, religion, sexual orientation, or ethnicity. Disability was added in 1994 when the Violent Crime Control and Law Enforcement Act was passed, and gender and gender identity was added under the Matthew Shepard and James Byrd, Jr. Hate Crimes Prevention Act that was passed in 2009. Additional categories of Sikhs, et al were added in 2012 after the Oak Creek massacre in Wisconsin. Evidence of bias can be applied, but are not limited, to murder, non-negligent manslaughter, forcible rape, aggravated assault, simple assault, intimidation, arson, and destruction, damage, or vandalism of property. The findings are to be published in an annual report in the Uniform Crime Reporting Program of the Federal Bureau of Investigation under the direction of the Attorney General in the Department of Justice. The Act also provides for the development and dissemination of educational materials for law
} 
While it generally reaffirmed the need for data collection on the incidence of hate violence nationally, it was significant in another way: the hearing was the first time that the issue of anti-Arab violence was acknowledged at the federal level. Just seven months earlier, on December 10, 1985, Federal Bureau of Investigation Director William Webster suggested that the nation's Arab and Muslim American community was living in a "zone of danger," alluding to the murders of activist Alex Odeh in Southern California and Ismael Faruqi, an Islamic scholar, and his wife in Philadelphia. ${ }^{83}$ Various representatives of the Arab and Muslim American community testified at the hearing about the impact of this violence. An analysis of their testimonies offers important insights into the politics of hate violence during a period of racist hysteria and religious bigotry.

The twenty-fifth anniversary of the passage of the Hate Crime Statistics Act in April 2015 is an occasion to not only pause and assess the impact of this law, but also to understand the political context and the legislative machinations that led to the passage and signing of the nation's first federal hate crime legislation. The "Ethnically Motivated Violence Against Arab-Americans" hearing as well as six other committee hearings were essential for determining how hate crimes would be defined, what its sources were, and what solutions would be proposed. My primary focus in this article is to examine the ways in which the hearing represents Arab and Muslim American subjectivity as simultaneously victim, American, citizen, and political subject. I show how each version reveals various stakes of, interests in, and contradictions about being Arab and Muslim American while also demonstrating the ways in which each testimony was committed to supporting the Hate Crime Statistics Act.

Four significant themes can be discerned in the hearing. First, two recent historical events were repeatedly invoked throughout the hearing. The murder of Alex Odeh on October 11, 1985 hung heavily over the hearing. Odeh was Regional Director of the ArabAmerican Anti-Discrimination Committee and a respected community leader in Southern California. Family members and fellow community leaders widely believed that his murder was the clearest example of anti-Arab and anti-Muslim discourse escalating into violence, as his death was widely thought to be the result of years of intensifying racist sentiments against Arab and Muslim American communities. Furthermore, Odeh's death revealed the inability and unwillingness of current legal and political institutions to intervene and protect individuals and communities from hate violence. The other historical event that was frequently referenced during the hearing was the 1978-1980 Federal Bureau of Investigation anti-corruption operation, "ABSCAM," which still lingered in the memory of the Arab and Muslim American community. In the ABSCAM operation, so named for a fictitious Arab corporation, "Abdul Enterprises Ltd.," undercover agents posed as "Arab sheikhs" to lure politicians and public officials into bribery scandals. Once the details of the operation were made public, the FBI was embroiled in a wave of controversy over its questionable investigative procedures and surveillance tactics. In the wake of this scandal, Executive Assistant Director of the FBI Oliver B. Revell's testimony about becoming more "sensitive" to the needs of the Arab and Muslim American community was received with much skepticism.

Second, some witnesses linked U.S. foreign policy to the rise of domestic anti-Arab and anti-Muslim discourses. Mervyn Dymally, former Lieutenant Governor of California

enforcement agencies to use in training officers to recognize and record hate crimes, and to foster better working relationships with various communities in order to improve crime control responses.

83 Shenon, "F.B.I Chief Warns Arabs of Danger." 
(1975-1979), made the connection between the power of inflammatory rhetoric by political leaders, in conjunction with hostile U.S. foreign policy in the Arab nations, and the fomenting of anti-Arab and anti-Muslim sentiments in American society. The discourse of political leadership can have social and political effects that can exacerbate and intensify racial and religious tensions. As these hearings made clear, U.S. foreign policies, especially those mobilizing military assets in Arab nations, could antagonize race relations in the U.S. under the banner of patriotism and contribute to bias-motivated attacks against Arab and Muslim Americans. Dymally's testimony underscored this powerful link, and specifically criticized President Ronald Reagan.

Third, the testimonies articulated a discourse of Arab and Muslim American subjectivity as predominantly assimilative. Committee members and witnesses tended to agree that what threatened the road to democratization and Americanization was organized racism and religious bigotry. However, this perspective represented an uncritical view of state power as a functional, and distinctly race- and religion-neutral, instrument.

Fourth, political enfranchisement and civic participation were avowed goals for the community, and hate violence came to be known as an obstacle. If hate violence has the effect of undermining and obstructing the full participation of a community in a free and democratic society, then strengthening political and electoral participation was paramount. However, political mobilization, representation, and civic participation should be essential goals in and of themselves for any community, not simply a response to the threat of violence. Analyzing the hearing on "Ethnically Motivated Violence Against ArabAmericans" in terms of the four themes above - the weight of recent historical events, the relationship between U.S. foreign policy and domestic anti-Arab and anti-Muslim discourses, Arab and Muslim American subjectivity as assimilative, and hate violence as an obstruction to political enfranchisement - will highlight how the causes and effects of hate violence in the U.S. came to be understood and defined for the purposes of federal legislation and in relation to the status of the Arab and Muslim American community in the U.S. in the 1980s.

\section{THE POLITICS OF COMMITTEE HEARINGS}

Before examining the testimonies given during the hearing, a brief overview of the function of committee hearings in general will clarify the purpose of the "Ethnically Motivated Violence Against Arab Americans" hearing within the legislative history of the Hate Crime Statistics Act. At a basic level, committee hearings are a way to gather information for committee members about a particular piece of legislation. Ideally, committee hearings are like educational forums where lawmakers listen to a select list of experts, such as lobbyists, citizens, business leaders, and academics, including even the occasional high profile entertainer. For example, political humorist and satirist Stephen Colbert testified in 2010 in a House Judiciary Committee subcommittee on the state of immigrant and migrant workers, and in 2002, Michael J. Fox and Muhammad Ali appeared before the Senate Appropriations Subcommittee on Health and Human Services to argue for additional monies for research into Parkinson's disease. ${ }^{84}$ Each individual called before the committee gives a short presentation about the topic at hand. Committee members can gather information, ask questions, make comments, and analyze findings, all of which presumably enables them to act as informed lawmakers.

${ }^{84}$ For an extended list of celebrities and their testimonies, see ProQuest Congressional Hearings Digital Collection Famous (Celebrity) Witnesses: http://proquest.libguides.com/quick_start_hearings/famouscelebs. 
The hearing on "Ethnically Motivated Violence Against Arab-Americans" was a strategic legislative opportunity to move the Hate Crime Statistics Act forward. It served as a chance for the committee to further their understanding of hate violence, and it was an opportunity for Arab and Muslim American representatives to articulate their support for the HCSA, along with their ideas about what hate violence was, and what the federal government ought to do about it, all of which would be entered into the public record.

One of the important functions of a committee hearing is that it assists committee members in deciding whether new laws, or changes to current ones, are needed to address immediate problems. This hearing provided additional evidence for the advancement of hate crimes legislation on the federal and individual state levels. It laid the foundations for penalty enhancements, expanded coverage for future group protections, especially for religious identity, and augmented the powers of the Federal Bureau of Investigation under the direction of the Attorney General in the Department of Justice. Witnesses called to testify articulated what it meant to be Arab and Muslim American - their experiences, fears, and desires - in ways that deeply resonated with the possibilities of achieving the American Dream, but they also expressed anxieties over the obstacles that stood in the way.

\section{"The Subcommittee will come to order."}

Witnesses summoned to the hearing were mostly, though not entirely, a "who's who" of prominent Arab and Muslim Americans. Testifying at the hearing were Nick Joe Rahall, Representative from the State of West Virginia; Oliver B. Revell, Executive Assistant Director of the Federal Bureau of Investigation; Mary Rose Oakar, Representative from the State of Ohio; James Abourezk, Chairman of the Arab-American Anti-Discrimination Committee; David J. Sadd, Executive Director of the National Association of ArabAmericans; David M. Gordis, Executive Vice President of the American Jewish Committee; Hyman Bookbinder, Washington Representative, also of the American Jewish Committee; Mervyn M. Dymally, Representative from the State of California; Norma Odeh from Santa Ana, CA; Mohammad Mehdi, President of the American Arab Relations Committee; Abdeen Jabara, from Detroit, MI; James Zogby, Executive Director of the Arab-American Institute; Bonnie Rimawi, former Regional Director of the Arab-American AntiDiscrimination Committee; Michael Smith, Seafarers Legal Services; Robert Crane, Islamic Society of North America; Sayed Gomah, Islamic Society of Houston, TX; and Rema Simon of Boston, MA.

The Chair of the Committee, Congressman John Conyers, Jr. (D-Michigan), opened the hearing by decrying what he called a "national tragedy" of violence against Arab Americans. ${ }^{85}$ Conyers cited FBI Director Webster's remarks that Arab Americans are in a "zone of danger" and that "Jewish extremist groups" have resorted to political assassinations to silence critics of the state of Israel. Conyers proclaimed that "ethnically motivated violence against Arab-Americans ... must be perceived as a threat to all in our society." 86 Anyone or any group who sought to deny "fundamental democratic freedoms" on the basis of an identity should "pay a very high cost." " He continued, "This can only be accomplished

${ }^{85}$ U.S. Congress House, Ethnically Motivated Violence Against Arab-Americans: Hearing Before the Subcommittee on Criminal Justice of the Committee on the Judiciary, 99th Congress, 2nd Session (U.S. Government Printing Office, 1986), 1.

86 Ibid., 2.

87 Ibid. 
with vigorous and swift investigation and prosecution by both Federal and local authorities." ${ }^{88}$ Conyers also noted for the record that federal investigations into the attacks, especially of the murder of Alex Odeh, had not produced "a single indictment." ${ }^{89} \mathrm{He}$ reaffirmed the commitment of the federal government to the idea that the perpetrators cannot go unpunished, and that such violence cannot be tolerated. He ended solemnly, "In the memory of Alex Odeh and all that this country stands for, we must insist upon it." $" 90$

\section{TESTIMONY OF NORMA ODEH}

The centerpiece of the hearing was without a doubt the testimony of Norma Odeh, the wife of Alex Odeh, who was murdered on the morning of October 11, 1985 as a tripwire caused the door to the office of the Arab-American Anti-Discrimination Committee to explode when he opened it. Alex Odeh was the regional director of the ADC's southern California office. ${ }^{91}$ Close friends and community members strongly believed that the office bombing that resulted in Odeh's death was in retaliation for Odeh's words following the hijacking of the Achille Lauro cruise ship on October 7, 1985 during which Leon Klinghoffer, a Jewish American, was taken hostage and cruelly murdered. In a television interview, Odeh condemned the terrorist acts, but defended the leader of the Palestine Liberation Organization, Yasser Arafat, as a "man of peace." 92 Odeh was referring to Arafat's role in securing the release of the hostages aboard the Achille Lauro, but family members believed his words were taken out of context. ${ }^{93}$ Media hysteria in the coverage of the Achille Lauro atrocity fueled anti-Arab sentiments in the U.S. that led to numerous death threats to Arab American organizations, leaders, supporters, and families across the nation. ${ }^{94}$ Norma Odeh testified that her husband received numerous death threats prior to his murder. Yet he remained dedicated and steadfast in his work. The danger did not sway "his convictions or diminish the energy with which he dedicated himself." 95 The tragedy of her family's loss was intensified as the public discourse surrounding Alex Odeh's death was met with a deafening silence on the part of the U.S. political leadership: "How is it that an American citizen, brutally murdered by terrorists on our own soil, has not received full recognition and support from our Government, as did the victims of international terrorism during the Achille Lauro incident? ... While our Government apprehends terrorists half way around the world, it seems helpless in the face of domestic terrorism directed against Arab-Amercans." 96 Other witnesses also testified that numerous high ranking and high profile politicians failed to acknowledge the murder of Alex Odeh by terrorists even though the murder of Leon Klinghoffer was widely condemned. This was an obvious double standard regarding whose

\footnotetext{
88 Ibid.

${ }^{89}$ Ibid.

90 Ibid.

91 Ibid., 106.

92 See Mark Landsbaum, “Odeh Family Hails Grand Jury Probe of Anti-Arab Crimes,” LA Times, 04/04/1987, accessed on: http://articles.latimes.com/1987-04-04/local/me-1050_1_alex-odeh.

93 See Associated Press, "Rights Groups Urge Probe into 1985 US Bombing," Al Jazeera, 09/15/2013, accessed on: http://www.aljazeera.com/news/americas/2013/10/rights-groups-urge-probe-into-1985-usbombing-2013101422237884739.html.

${ }^{94}$ House, Ethnically Motivated Violence Against Arab-Americans: Hearing Before the Subcommittee on Criminal Justice of the Committee on the Judiciary, 1-2.

95 Ibid., 106.

96 Ibid., 106-107.
} 
lives and which communities were valued. The official silence surrounding Odeh's death spoke volumes, even if unintended, about the federal government's disposition.

Norma Odeh continued to describe Alex's life and legacy, as one who worked for the community's constitutional rights, fought against racial discrimination, and valued the importance of "bringing people of all races and religions together to work side by side for the common good." Her hope was for Alex Odeh to not "die in vain." represented an opportunity to articulate the immediate need to investigate and resolve, the circumstances of Odeh's death, and to find justice for the Odeh family.

\section{TO BE IN A "ZONE OF DANGER"}

Representative Nick Joe Rahall (D-West Virginia) testified about the "wave of antiArab hysteria" driven by anti-Arab stereotypes in the media. He came to office in 1976, and represented West Virginia's Third Congressional District. Rahall was one of the few Arab American Representatives serving in Congress, and one of five Lebanese American Representatives with senior status. Rahall's testimony pointed to how political leaders in Congress had created an environment ripe for "terrorist attacks on Americans of Arab heritage right here on American soil." "In particularly, he criticized President Reagan's "Ramboism," a reference to the popular movie character Rambo played by Sylvester Stallone and popularly known for his mindless warlike brutality. Rahall also argued that rattling American sabers in Arab nations had the effect of creating an environment that sanctioned harassment, discrimination, and violence against Arab Americans. ${ }^{100}$ Fueling this "wave of anti-Arab hysteria" were news reports that continued to equate "Arabs" with "terrorists." According to Rahall's testimony, media stereotyping and inflammatory political rhetoric were a deadly combination that enabled anyone in society to exact revenge and mete out punishment. ${ }^{101}$ As Rahall continued to note in his testimony, Arab and Muslim Americans have become the "black sheep of the world" and "degraded to the role of subhuman[s]," causing the bonds of compassion and empathy to suffer as well. ${ }^{102} \mathrm{He}$ argued that this dehumanization was how the murder of Alex Odeh became possible, with Odeh as "a victim of terrorism on American soil.",103

Scholar Edward Said has warned of discursive constructions that reduce the complexity of the Arab and Muslim world to a "limited series of crude, essentialized caricatures" $" 104$ whose persistence would "make that world vulnerable" to violence. ${ }^{105}$ Rahall's testimony depicted the death of Odeh as the terrible price the community pays when negative representations of Arabs and Muslims reached the point where the prospect of violence was not only possible, but also permissible and rationalized. Rahall ended his testimony imploring the committee for leadership in a time of crisis: " $\Pi \mathrm{t}$ is high time that this anti-Arab, anti-Arab-American hysteria, which has engulfed this country, be calmed. It

\footnotetext{
${ }^{97}$ Ibid., 107.

98 Ibid.

${ }^{99}$ Ibid., 2.

100 Ibid.

101 Ibid., 2-3.

102 Ibid., 3.

103 Ibid.

104 Edward Said, Covering Islam: How the Media and the Experts Determine How We See the Rest of the World, Rev. ed., 1st Vintage Books ed. (New York: Vintage Books, 1997), 26.

105 Ibid.
} 
tears at the moral fabric upon which this great Nation of ours is woven." ${ }^{106}$ He continued to assert the unwavering rights of Americans to be protected from such violence as well as to be able to live freely as a people, and referenced the moral compass that guides the political leadership to fight hate violence: "The right for Arab-Americans [to live freely as a people] is being threatened, and this represents a serious crisis. This right must never be threatened for any ethnic group. Let all of us here today pledge to work together under your leadership, Mr. Chairman, and wipe out the ugly stain of prejudice and violence from the face of the Earth."107

Rahall's closing point accentuated one of the more common themes in the testimonies given about racial identity in a time of racist hysteria. Raising the issue of anti-Arab violence at the federal level was a significant political act, one that not only acknowledged the issue, but also afforded leaders of the Arab and Muslim American community a number of opportunities to recommend policy initiatives, advance the discourse about race and religious identity, and express other relevant concerns. Rahall's testimony was also a sign of things to come later in the hearing. While he rightly asserted that anti-Arab hysteria needed to "be calmed," he failed to understand how U.S. foreign policy and military actions abroad contributed to the groundswell of racist violence at home. While the media was an influential institution that could be considered culpable for fomenting such violence, it was the caustic rhetoric of political leadership and the deafening silence from his colleagues in the federal government that sanctioned the violence. This failure of political leadership, particularly by President Ronald Reagan, created the conditions for violence in the first place.

Mervyn Dymally, former Lieutenant Governor of California (1975-1979), saw the connection between political rhetoric and racist violence quite clearly, and he offered the strongest critique of the federal response to violence against Arab and Muslim American communities, including holding U.S. politicians at the highest levels accountable for the ways in which their words and actions contributed to an environment of anti-Arab stereotyping, prejudice, and violence. Dymally was elected as a Democrat from California to the $97^{\text {th }}$ Congress (1981-1993). A leader of the Congressional Black Caucus, Dymally became involved with the Arab and Muslim American community when an Arab American staff member was singled out on the conservative Christian Broadcast Network and labeled as a "terrorist" without the network interviewing the staff member or Dymally himself. ${ }^{108}$ The national broadcast occurred around the time of the murder of Alex Odeh. What distressed Dymally was that while other staffers had worked on the Alex Odeh case - Samoan, Jewish, African American, Latino - only the Arab American was singled out for harassment and personal attacks. This incident led him to believe that not enough was being done to protect the nation's Arab and Muslim communities.

Dymally condemned the current administration as "the most Arab-bashing administration of any in the history of America." ${ }^{109} \mathrm{He}$ continued, "To be Arab is to be Moslem and to be Moslem is to be Arab, and to be either is to be a terrorist. That's the line of reasoning. And they have set up a climate in the United States which makes all of these things ... possible." ${ }^{\prime 10}$ He provided a summary of a list of abuses, rapes, murders, assaults,

\footnotetext{
106 House, Ethnically Motivated Violence Against Arab-Americans: Hearing Before the Subcommittee on Criminal Justice of the Committee on the Judiciary, 4.

107 Ibid.

108 Ibid., 84.

109 Ibid., 85.

110 Ibid.
} 
vandalisms, and threats to Arab and Muslim individuals and families in their homes, schools, businesses, and mosques, from San Francisco, CA to Alexandria, VA. The complete list was submitted to the committee for the record. The work of his office and staff led him to conclusively assert that a wave of "terrorism against Arab-Americans" was present, and an exasperated Dymally stated, "I do not know as of this moment if anyone - at least I know that no one has been caught, no one been indicted, no one has been sentenced." 111 Additionally, he emphasized that there had been no cases where an Arab or Muslim American had been "caught, or prosecuted, or tried for any terrorism act against any American.... not a single case" in at least ten years. ${ }^{112}$

In his full testimony submitted to the Committee, Dymally illustrated the impact of the limited response of the FBI: "the likelihood of Arab Americans reporting these incidents to the FBI is slim because of their feeling that the FBI is not concerned for their well being. Moreover, the community feels that reporting these incidents to the FBI would only result in agents prying into their own lives rather than protecting them." ${ }^{113}$ But perhaps the most damning element in Dymally's submitted testimony was his critique of President Ronald Reagan's anti-terrorism policy, which had significant effects at home, fueling anti-Arab hysteria. While he summarized the texts in his public statements, his written statement included contributions from members of the Reagan administration to an anthology entitled, Terrorism: How The West Can Win (1987), edited by Benjamin Netanyahu, then Israel's ambassador to the United States. ${ }^{114}$ Contributors included then Secretary of State George Shultz, Senator Daniel Patrick Moynihan, former U.S. Ambassador to the United Nations Jean J. Kirkpatrick, National Security Council consultant Michael Ledeen, former Undersecretary for Political Affairs Eugene Rostow, former U.S. Attorney General Edwin Meese III, and former Federal Bureau of Investigation Director William Webster. ${ }^{115}$ According to Dymally's testimony, the anthology included views that "ascribe terrorism to Islam." "While Dymally was careful to acknowledge that members of the administration associated with the anthology did not explicitly refer to Islam as terrorism, he suggested that they implicitly sanctioned such a view and gave credence with their names to a project that rationalized U.S. foreign policy by perpetuating this link. Among the contributors whose views explicitly equated Islam with terrorism was former ambassador Netanyahu who wrote: "The root cause of terrorism lies not in grievances but in a disposition toward unbridled violence. This can be traced to a world view which asserts that certain ideological and religious goals justify, indeed demand, the shedding of all moral inhibitions. In this context, the observation that the root cause of terrorism is terrorists is more than a tautology."

According to Dymally, of all the figures who played a role in fueling the "zone of danger," and to whom could be attributed an environment of anti-Arab hysteria in the United States, the most significant was President Ronald Reagan. After the release of the TWA hostages on July 1, 1985, Reagan quipped to television technicians before a speech,

\footnotetext{
111 Ibid.

112 Ibid., 86.

113 Ibid., 93.

114 Ibid., 98.

115 Ibid. See also, Binyamin Netanyahu, Terrorism: How the West Can Win (New York: Avon, 1987).

116 House, Ethnically Motivated Violence Against Arab-Americans: Hearing Before the Subcommittee on Criminal Justice of the Committee on the Judiciary, 98.

117 Ibid., 99.
} 
"Boy, after seeing Rambo last night, I know what to do the next time this happens." the remark was not broadcast live, it was picked up by the microphone and rebroadcast on the television and the radio. After the U.S. bombardment of Libya, Reagan described Moammar Qaddafi as "this mad dog of the Middle East [who] has a goal of a world revolution, Moslem fundamentalist revolution which is targeted on many of his own Arab compatriots." 119 The bombing was in response to an incident that occurred six months after the hijacking of the Achille Lauro, on April 5, 1986, when a bomb killed three and wounded two hundred thirty at a nightclub in West Berlin. Seventy-nine U.S. servicemen were among the injured. Reagan held Libya responsible for the attacks, and over the objections of the international community, the U.S. retaliated with military strikes on April 15, killing forty people. In the U.S., Arab and Muslim American community members braced for the worst as individuals and families were harassed and received threats, and their homes, businesses, and houses of worship were vandalized with the words, "Go back to Libya." ${ }^{20}$ Inflammatory statements by the President, Dymmally contended, uncritically and irresponsibly cast Islam as an underlying force in terrorism with global as well as domestic implications. These disparaging references, especially as spoken by the "leader of the free world," had specific domestic effects upon the country's perception of Islam, and the perception of Arab and Muslim Americans.

At these testimonies suggested, state power and hate violence determine each other vis-à-vis U.S. foreign policy in the Arab nations and the rise of anti-Arab and anti-Muslim violence and bigotry in the U.S. As the United States rattles its sabers abroad and routinely, and with impunity, threatens its own form of terror in the Arab nations, violence and bigotry against Arab and Muslim Americans in the U.S. increases dramatically. In this period of the 1980s, at a time of considerable anti-Arab and anti-Muslim hysteria, the idea of hate violence against Arabs and Muslims was not just a matter of counting incidents and occurrences, but also of contextualizing the weight of the competing interests responsible for why a "zone of danger" existed in the first place. Central to this "zone of danger" was how this particular violence was more than acts of prejudice and violent bigotry, but was also a discursive and systematic effect that represented Islam and the Arab world as threats to the United States.

"CONCERNED AND SENSITIVE": THE FEDERAL BUREAU OF INVESTIGATION

Perhaps the most informative yet frustrating testimony in this hearing came from Oliver B. Revell, Executive Assistant Director of the Federal Bureau of Investigation. He assured the Committee and the Arab and Muslim American community that the Federal Bureau of Investigation was "definitely aware of and greatly concerned about the attacks perpetrated." ${ }^{121}$ He added that the investigation of Alex Odeh's murder was elevated along with a number of other bombings to the "highest national priority," and that the exchange of "pertinent intelligence information" with other field offices in the country was leading to

\footnotetext{
118 Ibid., 100. See http:/ /www.loc.gov/exhibits/hope-for-america/politics-and-camp.html\#obj1 and also Los Angeles Times, “Reagan Gets Idea From ‘Rambo’ For Next Time,” http://articles.latimes.com/1985-0701/news/mn-10009_1_hostage-crisis (accessed 14 August 2014).

119 Ibid. See also President's News Conference, 9 April 1986,

http://www.presidency.ucsb.edu/ws/index.php?pid=37105 (accessed 14 August 2014).

120 Ibid., 2.

${ }^{121}$ Ibid., 9.
} 
the "development of a national strategy" with "teams of investigators" engaged in antiterrorist operations, and that they had and were pursuing suspects. ${ }^{122}$

Revell expressed the hope that members of the subcommittee and the Arab American community would continue to be patient and remain supportive of their continuing efforts. He reiterated the FBI's "deep sensitivity" to the Odeh family's loss, the community's tragedy, and the circumstances in which the murder occurred. He endeavored to resolve these investigations in an "expeditious manner." ${ }^{\text {123 }}$ Revell also clarified FBI Director William H. Webster's statement on December 10, 1985 regarding the "campaign of terror" against Arab and Muslim Americans: "I think we must be careful what we say, but I think I can say that Arab individuals, or those supportive of Arab points of view, have come into the rone of danger or targeting by the group as yet to be fully identified and brought to justice" (emphasis mine). ${ }^{124}$ Revell made similar statements to the U.S. Commission on Civil Rights in February earlier that year in referencing "certain extremist elements" that opposed Arab and Muslim American interests and their constitutional rights to express statements as well as peaceably assemble. ${ }^{125}$ Although FBI Director Webster initially identified those "extremist elements" as members of the Jewish Defense League and the Jewish Defense Organization, Revell later qualified these statements suggesting that the assertion was based on "intelligence available" at the time, but that they were still in the preliminary stages of the investigation.

Revell's testimony revealed the perspectives of the agency, especially in a time of racist and religious violence. Chairman of the Committee Conyers reiterated FBI Director William Webster's "zone of danger" comment and asked if the agency had taken any "special steps" to ensure the safety of Arab and Muslim Americans. ${ }^{126}$ Revell responded that the FBI did not have "the authority nor the capability to protect," but only the possibility of "interventive action" and the "ability to intervene in ongoing conspiracies." "27 The FBI, said Revell, did not provide "protective security." 128 Revell further elaborated that the FBI had increased their level of investigation after the murder of Alex Odeh, and since then there had been no further incident - or at least none that he was aware of. The agency's position on this matter was "the ultimate prevention will be the successful identification and prosecution of those responsible. The best way to prevent terrorism is to put the terrorists in prison, and this [is] our responsibility." 129 As a matter of procedure, Revell stated that when they received information or intelligence about anyone at risk, they would contact those individuals as well as local law enforcement in the area who could then take appropriate protective measures. ${ }^{130}$

Revell's testimony was met with disbelief by some of the key Committee members and witnesses at the hearing. While Revell appeared committed to solving the murder of Alex Odeh and acknowledged the wave of anti-Arab hysteria that may have produced an atmosphere ripe for such violence to occur, he framed the agency's resolve in narrowly defined terms: by law, jurisdiction, and resources. Revell further testified that the violence that had been perpetrated may not have been entirely committed by white supremacists or

\footnotetext{
122 Ibid.

123 Ibid.

124 Ibid., 9-10.

125 Ibid., 10.

126 Ibid., 12.

127 Ibid.

128 Ibid.

${ }^{129}$ Ibid.

130 Ibid.
} 
Jewish extremists. They could have been random acts of violence or crimes of opportunity such as robbery. Revell also pointed to the legal limitations of the agency, arguing that not all violations are federally related, and therefore would not require the resources of the Federal Bureau of Investigation. State and local infractions would be the proper domain of local law enforcement which he presumed would be perfectly capable of handling these cases. Finally, Revell maintained the agency's "sensitivity" to the concerns of the Arab and Muslim American community, and their commitment to the diligent pursuit of any investigation in which there is a "legal justification to do so." 131

In fact, the question of legal justification was precisely why this hearing had been called, and more broadly, why federal hate crimes legislation was being considered in the first place. The purpose of the hearing was to consider what hate violence was, why local and state law enforcement were unable or unwilling to respond to such violence, how best to combat it, whether new laws should be enacted to address it, and whether or not the FBI should be the primary agency to respond to it. Revell's testimony may have been unsatisfactory for the Arab and Muslim American community, but he made an important argument for the expansion of the agency's power by revealing the its narrowly defined purview and thus highlighting the need for "legal justification." ${ }^{132}$ Revell's testimony also raised broader questions among the committee members about enforcing federal civil rights statutes and investigating hate crimes in general. Although hearing after hearing decleared the necessity of expanded federal power in combatting hate violence, including this hearing on anti-Arab violence, it was unclear whether an agency like the FBI ought to be granted broader institutional authority and expanded surveillane and police powers given its abusive history with communities of color, labor unions, and civil rights leaders.

\section{ARAB SHEIKHS, FANCY SUITS, AND STACKS OF \$100 BILLS}

Arab and Muslim Americans had reason to question Revell's commitment to "sensitivity." Representative George W. Crockett (D-Michigan) charged that the agency's investigative actions had "racial implications." ${ }^{33}$ Revell took exception to the remark, pointing to the agency's long and successful history in investigating and arresting individuals connected to organized racism. In the past two years, he argued, the agency had over thirty successful prosecutions against the Aryan Nation, for example. He reassured members of the Committee and the community that the agency was using the "same dedication and the same application" of their skills to any investigation. ${ }^{134}$

However, the FBI's historical role in communities of color was unsettling, in particular as it related to practices of surveillance, questionable searches and seizures, and known practices of coercion and extreme violence against civil rights leaders, communities of color, the progressive left, and organizations such as labor unions and the Black Panther Party, to name a few. ${ }^{135}$ Despite Revell's claim of the FBI being "sensitive" to the needs of Arab and Muslim Americans, their perceptions of and lived experiences with the agency told a different story, one that involved extralegal abuse, selective violence, biased investigation,

\footnotetext{
131 Ibid.

132 Ibid.

133 Ibid.

134 Ibid., 13.

135 For files regarding this history of the FBI, see FBI Records: The Vault, “COINTELPRO,” n.d., accessed January 24, 2015, http://vault.fbi.gov/cointel-pro/.
} 
and agents operating at their own discretion. These concerns were underscored in the wake of the ABSCAM scandal, a two-year sting operation conducted by the Federal Bureau Investigation from 1978 to 1980 to investigate public corruption. ${ }^{136}$ Under the direction of the Department of Justice, the operation videotaped numerous federal, state, and other public officials in New York, New Jersey, and Philadelphia accepting bribes from a fictitious "Arab" company called "Abdul Enterprises Ltd." in exchange for political favors, contracts for multi-million dollar casino businesses, and permanent residency in the United States. Operation "ABSCAM" operated with little guidance, let alone oversight concerning their activities. Although the operation netted numerous corruption charges, the FBI was heavily criticized for various unethical procedures in undercover activities, for the nature of its entrapment operation, and for undercover agents' involvement in illegal activities. The American-Arab Relations Committee condemned in particular the use of undercover FBI agents posing as fictional "Arab sheikhs" who served to reinforce prevailing popular stereotypes. ${ }^{137}$ Flashing "stacks of $\$ 100$ bills" presumably from oil wealth, and wearing "fancy suits and improvised headdresses," the operation played up the racial stereotypes of affluent "sheikhs" to net its victims, including some who were financially distressed. ${ }^{138}$ This operation was still fresh in the minds of the Committee members and the witnesses testifying that day.

Among the Committee member and witnesses who viewed Revell's testimony with disappointment, skepticism, and frustration was Representative Mary Oakar (D-Ohio), who connected memories of the ABSCAM scandal to the lack of progress in the Alex Odeh investigation by expressing her hope that the FBI would pursue those who had caused Alex Odeh's death with the same zeal that "they stereotyped Arab-Americans." "139 Oakar then took a moment to praise her fellow colleagues on their swift condemnation of the ABSCAM operation, noting the diversity of the individuals on record: "I was very, very pleased, Mr. Chairman, that black American Members of Congress, and Jewish-American Members of Congress, and Anglo-American Members of Congress, Japanese-American Members of Congress, Polish-American Members of Congress, as well as others joined with me and sent a letter to the FBI indicating how reprehensible they felt it was to stereotype any group, let alone Arabs." 140 In her testimony, Oakar emphasized this point further to ensure that the actions of the FBI would be consistent with their intentions. ${ }^{141}$

\section{ON BEING ARAB AMERICAN}

\footnotetext{
${ }^{136}$ For files regarding Operation ABSCAM, see FBI Records: The Vault, "ABSCAM," n.d., accessed November 28, 2014, http://vault.fbi.gov/ABSCAM.

137 This operation was recently popularized in a fictionalized account in the hit movie, American Hustle (2013), which opens with the text, "Some of this actually happened."

138 Richard Leiby, "To the Players in Abscam, the Real-Life 'American Hustle, the Bribes Now Seem Quant,"

The Washington Post, December 26, 2013, accessed November 28, 2014, http://www.washingtonpost.com/lifestyle/style/to-the-players-in-abscam-the-real-life-american-hustle-thebribes-now-seem-quaint/2013/12/26/d67648c2-6c15-11e3-a523-fe73f0ff6b8d_story.html. See also, Peter Slen and Gregory Wallance, “1980 Abscam Scandal”, January 24, 2014, accessed November 28, 2014, http://www.c-span.org/video/?317288-3/1980-abscam-scandal; Leiby, "To the Players in Abscam, the RealLife 'American Hustle, the Bribes Now Seem Quant"; and FBI Records: The Vault, "ABSCAM", n.d., -, accessed November 28, 2014, http://vault.fbi.gov/ABSCAM.

${ }^{139}$ House, Ethnically Motivated Violence Against Arab-Americans: Hearing Before the Subcommittee on Criminal Justice of the Committee on the Judiciary, 19.

140 Ibid.

141 Ibid.
} 
In addition to addressing the political context of anti-Arab and anti-Muslim sentiment in the U.S. and some of the words and actions responsible for these discourses, the hearing also presented community leaders with an occasion to define Arab American identity and communities. No other figure with as much stature and conviction as Representative Mary Oakar (D-Ohio) would speak about the issues, concerns, and challenges that the Arab American community faced at the time. However, she ended up defining the identity of the Arab American community rather narrowly. Her testimony circumscribed anti-Arab and anti-Muslim violence as a domestic issue and an American discourse rather than as a phenomenon intimately tied to U.S. foreign policies abroad. Her testimony also provided a strategic fit with the legislative agenda in that it prominently featured prejudice as the ideological rationale for understanding what hate violence was for the Committee members, thereby laying the grounds for the turn away from critiques of organized racism in favor of punishment for individual acts of prejudice.

Mary Rose Oakar was born in Cleveland, Ohio, on March 5, 1940, to parents of Lebanese and Syrian ancestry. She served sixteen years in the House of Representatives representing the state of Ohio from 1977-1993. She was dedicated to improving the economic security and welfare of women, and advancing the case for women's rights, but on certain issues she often came into conflict with the Democratic majority, such as in her prolife stance. As one of the few Arab Americans serving in Congress during the 1980s, she criticized President Ronald Reagan's foreign policy stance towards Israel. Despite her sometimes controversial positions, she was able to become an influential figure in the Democratic Party. ${ }^{142}$

Oakar began her testimony by praising the work of her colleagues on the Judiciary Committee and the Subcommittee, whose work in civil and human rights protected not only Americans but everyone "throughout the world." ${ }^{143}$ The most persuasive part of Oakar's testimony was her ability to connect the Arab American experience of prejudice and stereotypes with other racial and ethnic groups, including Japanese Americans, Jewish Americans, and Eastern European Americans. ${ }^{144}$ It was a strategic gesture that linked the root causes of destructive behaviors to prejudice as the animating set of beliefs that had the potential to lead to violence. She appealed to the shared experiences of different groups as a basis for seeing racism and ethnic hostility as a universal experience.

However, this perspective glossed over the different institutional histories of each group and ignored the different ways governmental policies like slavery, genocide, race-based exclusion, and colonization have impacted African Americans, Native Americans, Asian Americans, and Latino Americans differently. Furthermore, prejudice was appealing as a causal factor as it tended to reduce the complexity of bias-motivated violence to individual acts of ignorance, while failing to acknowledge the significance of social and economic factors such as poverty, inequality, demographic changes, and unemployment. While no one factor could be identified as the cause of hate violence, several factors could contribute to an environment that could lead to incidences of hate. In defining bias as an individual behavior

\footnotetext{
142 See the biography of Representative Mary Rose Oakar at: House, U.S. Congress, "Mary Rose Oakar," History, Art and Archives, n.d., accessed November 28, 2014, http://history.house.gov/People/Listing/O/OAKAR,-Mary-Rose-\%28O000001\%29/.

143 House, Ethnically Motivated Violence Against Arab-Americans: Hearing Before the Subcommittee on Criminal Justice of the Committee on the Judiciary, 19.

144 Ibid., 20.
} 
and criminality as a question of culpability, hate violence became less about historical subjects and unequal power relations and more about individual conduct, prejudice, and the influence of stereotypes. Oakar's testimony, along with that of many others like her in these committee hearings, was critical in shifting the emphasis away from addressing the problem of hate violence as one of organized racism and violent bigotry. Instead of targeting the activities of the $\mathrm{Ku}$ Klux Klan or the Aryan Youth Movement, the focus shifted to random acts of prejudice and bigoted individuals. As a result, policy discussions centered upon the need for criminal penalties and enhanced punishments, and increased federal interventions in response to individual conduct became the predominant policy option. Even though ample evidence suggested that educational programs and social policies aimed at building, supporting, and strengthening community bonds could be powerful initiatives to dismantle hate, only sentencing enhancements were adopted by the federal government as the primary tool to "combat" hate violence.

In her testimony, Oakar connected racial stereotypes in the media and racial prejudice as salient factors in the rise of anti-Arab violence. She cited the "Rambo-like Arab terrorist who just shoots up everybody," in major movies as well as caricatures in children's cartoons such as "Abdul O" and "Abdul the Butcher" in Popeye and Woody Woodpecker that reinforced negative representations of Arabs in the United States and around the world. ${ }^{145}$ Oakar noted that she initially dismissed these as jokes, but after the death of Alex Odeh, she worried about the cumulative effects of these images on people, especially upon those who were willing to engage in bias-motivated attacks. Describing the effects of these media stereotypes as the most "blatant bigotry," she articulated this relationship of prejudice to violence as a continuing problem of peace. ${ }^{146}$ Oakar's testimony gave voice to a deep aspirational idea of what America represents, as a country where full participation, free expression and free association, are values and freedoms that ought to be exercised without consideration of one's rank, status, religious affiliation, national origins, or race. Yet, Oakar lamented, the unfortunate reality persisted that prejudice, from its manifestations in popular media to its physically violent expressions, continually marginalized and disempowered communities of color including Arab and Muslim communities in the United States.

Oakar's testimony made strategic political and legislative sense for the argument for passing not only the Hate Crime Statistics Act, but also future hate crime legislation. She articulated the political logic of the perniciousness of prejudice left unchecked, the danger of negative media stereotypes, and the need for better law enforcement, in particular the necessary role of the federal government as an instrument for liberty, freedom, democracy, and equality. She expressed the need for lawmakers to address egregious errors in society. Her testimony set up a critical framework for the discussion of how hate violence endangered the nascent political and civic voices of Arab and Muslim Americans, as the next testimonies will suggest.

\section{THE ROAD TO POLITICAL ENFRANCHISEMENT}

Like Oakar, former Representative James Abourezk, now Chairman of the ArabAmerican Anti-Discrimination Committee, also testified to the insidious effects of prejudice,

\footnotetext{
145 Ibid., 20-21. See also Jeremy Earp and Sut Jhally, Reel Bad Arabs: How Hollywood Vilifies a People (Media Education Foundation, 2006).

146 House, Ethnically Motivated Violence Against Arab-Americans: Hearing Before the Subcommittee on Criminal Justice of the Committee on the Judiciary, 21.
} 
though he emphasized its consequences in terms of the political participation of Arab American communities. Speaking directly about the death of Alex Odeh, Abourezk avowed that the current political leadership could contribute to an atmosphere of hostility or even facilitate violence through their silence if they allowed "demagoguery against Arabs" to continue unchallenged. ${ }^{147}$ Political leadership, he argued, especially at the highest level, can send the wrong message to the people. While Abourezk expressed his thanks for the FBI's work on the investigation, and their "sensitivity" in addressing the concerns of the Arab and Muslim community, he also admonished the agency for its continued harassment of Arabs and Muslims. Explicit in Abourezk's testimony is the fact that such harassment had the overall effect of chilling the political participation of Arab and Muslim Americans. Abourezk contended that the political enfranchisement of Arab and Muslim Americans rested on the fundamental right to the free exercise of participation and association. On occasion, the exercise of such rights might involve a critique of U.S. foreign policy in the Arab nations, and sometimes those critiques could call into question foreign aid to the state of Israel and its continued occupation of Palestine. ${ }^{148}$ These activities fall within the protection of free speech, he argued, and they do not warrant the scrutiny of the FBI or any surveillance by any agency of the federal government.

Echoing the importance of political enfranchisement and the danger that hate violence presented as an obstacle to it was Mohammad Medhi, President of the American Arab Relations Committee, and Abdeen Jabara, a community leader from Detroit, MI. Medhi expressed his concerns about how violence against Arab Americans had the effect of limiting their participation in American political discourse. He brought up the murder of Professor Ismael Faruqi, an Islamic scholar and a Palestinian Arab who was murdered along with his wife in Philadelphia. Although local authorities were assisted by the FBI, they failed to produce leads or suspects in their investigation. Medhi worried that continued attacks, repeated harassment, and the failure of law enforcement agencies to intervene and prevent these attacks could produce a sense of alienation within the Arab and Muslim American community and a retrenchment from social, political, and economic life that would be detrimental to everyone.

Jabara's testimony was more explicit about the aims of anti-Arab and anti-Muslim violence, which was to "chill the exercise of the constitutional rights of Arab-Americans." 149 Jabara believed that the community was a "nascent voice," that Arab and Muslim Americans were beginning to organize "to play a role in this society," and to stand "shoulder to shoulder" for "jobs, peace, and justice, in the corridors of power." ${ }^{150}$ This rising tide of violence, he believed, was not the result of "random" or "thoughtless" attacks, but rather was aimed at circumventing the political and civic participation of Arab and Muslim Americans as a whole, that is, the violence that was aimed directly at their Constitutional rights. ${ }^{151}$

Finally, James Zogby, Executive Director of the Arab-American Institute, contextualized the Arab and Muslim American experience as another chapter in America's political story, a "new ethnic and political constituency" over 2.5 million strong and

\footnotetext{
147 Ibid., 34.

148 Ibid., 35.

149 Ibid., 110.

150 Ibid.

151 Ibid.
} 
growing. ${ }^{152}$ According to Zogby, the path to political enfranchisement was a success story that was unfolding. However, the "vilification," "defamation," and "outright violence against leaders and institutions" had been serious threats to this path for the past fifteen years and had cost the lives, property, and ability of many to exercise their constitutional rights. ${ }^{153}$ Reiterating previous critiques of the FBI for failing to produce "a single indictment" and, in some cases for being the very perpetrators of these attacks, he added to criticisms of their overzealous focus on Arab and Muslim Americans, energies he felt would be better spent investigating the perpetrators of anti-Arab violence. ${ }^{154}$

Zogby emphasized that this violence took place in a broader context of anti-Arab and anti-Muslim hostilities that contributed to the undermining of the ability of Arab and Muslim Americans to exercise their civil liberties and ensure the protection of their civil rights. ${ }^{155}$ If this domestic terrorism continued unabated, Zogby feared that the community would face political exclusion, blacklisting, and more fundamentally, the inability to define their identity on their own terms. Zogby's testimony advocated for more than selfdetermination; he also called for "self-definition," "legitimacy," and the collective expression of "political and cultural rights." 156

\section{CONCLUSION}

The findings of the Committee hearing contributed significantly to the legislative agenda that assisted in passing the Hate Crime Statistics Act four years later in April 1990. Committee members, aided by their newfound knowledge about the Arab and Muslim American experience, revealed gaps in the FBI's investigations in hate violence. New political alliances and coalitions were made as African American senior leadership and their Arab and Muslim American counterparts helped fashion new understandings about working with the FBI given its problematic histories with communities of color. However, the House committee hearing on anti-Arab violence was also one of several important hearings that slowly shifted the discourse of hate crime legislation from addressing the dangers and legacies of organized racism and violent bigotry to one of personal conduct expressed as prejudice, the political discourse that best suited the neo-conservative policies of the ReaganBush administration. In defining Arab and Muslim American identity within the mainstream narrative of ethnic assimilation, as best exemplified by Oakar's testimony, hate violence was relegated to a social abberration rather than seen as constitutive of unequal power relations in American society. Even though the powerful testimonies from Dymally and Rahall made the link between anti-Muslim and anti-Arab violence within the U.S. to U.S. foreign policy abroad explicitly clear, the resulting passage of the Hate Crime Statistics Act and subsequent hate crime legislation did not necessarily lead to laws and policies that addressed the dangers of organized racism or institutional factors that could reproduce an environment of hate. Instead, what subsequent federal and state legislators have essentially passed in the ensuing decades was enhanced carcerality as the core feature of hate crime legislation.

\footnotetext{
152 Ibid., 111.

153 Ibid., 111-112.

154 Ibid., 112.

155 Ibid.

156 Ibid., 114.
} 
While the testimonies from Abourezk, Jabara, and Zogby framed the dangers of hate violence as an obstacle to political enfranchisement, they did so in a manner that failed to acknowledge the racial and economic inequality in Arab and Muslim American communities, and the institutional and structural conditions that enabled and sustained an environment of hate. This is not to say that political representation, electoral voting, "get out the vote" campaigns, and other formal means of political representation are not important means of to empowering a community. But the road to political empowerment does not necessarily mean an end to hate violence. Such empowerment might actually intensify hate.

Finally, even though testimonies criticized the FBI's operations, the end result of this committee and other hearings laid the groundwork for expanding the agency's domain and surveillance powers for future hate crime legislation in the 1990s, and more importantly, for "anti-terrorism" legislation after 9/11, by highlighting the inability and/or unwillingness of local and state law enforcement to investigate and prosecute hate crimes. Many testimonies in this hearing demonstrated the need for expanded federal powers and new laws to address organized racism and religious violence. In some specific testimonies, witnesses cited the Federal Bureau of Investigation as the agency most perfectly suited to handle these kinds of situations, given the proper resources, training, and of course, legal authority. No one could have known in 1986 how their words and actions would help shape the role of the FBI in the aftermath of the events of September $11^{\text {th }}, 2001$, which blurred definitions of domestic terrorism, hate violence, and international terrorism. "Domestic terrorism" which would have meant organized white supremacy in the 1980s, shifted to risk and threat assessments of Arab and Muslim Americans in a post-9/11 moment. Enhanced by provisions in the USA Patriot Act and the dismantling of the Foreign Intelligence Surveillance Act, the FBI, which was positioned to be the primary law enforcement unit through which hate violence could be challenged, became the very tool through which the Arab and Muslim American community would be investigated, scrutinized, and surveilled. No one testifying at the hearing or sitting as a committee member in 1986 could have known what was to come, specifically the degree to which the agency's powers would increase, and the resulting damage that would then be done to the Arab and Muslim American community or to the delicate fabric of civil rights and civil liberties in the United States. The Hate Crime Statistics Act has become an invaluable tool that, in addition to counting the number of hate crimes committed annually, has been an important resource to law enforcement agencies to improve the recognition of and response to hate violence. It has also become an outstanding source for researchers and and policy analysts interested in discovering new trends in hate violence. Yet the implications that occurred during the "Ethnically Motivated Violence Against Arab-Americans" hearing go beyond their effect upon the passage of the Hate Crime Statistics Act to larger questions of racial and religious identity in the U.S. context, the relationship between foreign policy and domestic disocurse, and the role of the federal government in the policing of hate.

\section{EPILOGUE}

Almost thirty years later, Alex Odeh's murder remains unsolved case and is still a stark example of justice denied for the Arab and Muslim American community. Police arrested Joseph L. Young, 41, and charged him with the murder of Professor Ismael Faruqi and his wife, Lois Lamya al-Faruqi, who were killed in Wyncote, Pennsylvania, on May 27, 1987. Anmar al-Zein, their pregnant daughter, suffered critical injuries, but she and her baby 
survived. On July 11, 1987, a jury found Young guilty of committing two counts of firstdegree murder, and he was sentenced to death. 


\section{REFERENCES}

Earp, Jeremy, and Sut Jhally. Reel Bad Arabs: How Hollywood Vilifies a People. Media Education Foundation, 2006.

FBI Records: The Vault. "ABSCAM,” n.d. Accessed November 28, 2014. http://vault.fbi.gov/ABSCAM. . "COINTELPRO,” n.d. Accessed January 24, 2015. http:/ / vault.fbi.gov/cointel-pro/.

House, U.S. Congress. Ethnically Motivated Violence Against Arab-Americans: Hearing Before the Subcommittee on Criminal Justice of the Committee on the Judiciary. 99th Congress, 2nd Session. U.S. Government Printing Office, 1986.

House, U.S. Congress. "Mary Rose Oakar.” History, Art and Archives, n.d. Accessed November 28, 2014. http://history.house.gov/People/Listing/O/OAKAR,-Mary-Rose-\%28O000001\%29/.

Leiby, Richard. "To the Players in Abscam, the Real-Life 'American Hustle, the Bribes Now Seem Quant." The W ashington Post, December 26, 2013. Accessed November 28, 2014.

http://www.washingtonpost.com/lifestyle/style/to-the-players-in-abscam-the-real-life-americanhustle-the-bribes-now-seem-quaint/2013/12/26/d67648c2-6c15-11e3-a523-fe73f0ff6b8d_story.html. Netanyahu, Binyamin. Terrorism: How the West Can Win. New York: Avon, 1987.

Said, Edward. Covering Islam: How the Media and the Experts Determine How We See the Rest of the World. Rev. ed., 1st Vintage Books ed. New York: Vintage Books, 1997.

Shenon, Philip. "F.B.I Chief Warns Arabs of Danger." New York Times, December 11, 1985. Accessed November 24, 2014. http://www.nytimes.com/1985/12/11/us/fbi-chief-warns-arabs-ofdanger.html.

Slen, Peter, and Gregory Wallance. “1980 Abscam Scandal,” January 24, 2014. Accessed November $28,2014$. http://www.c-span.org/video/?317288-3/1980-abscam-scandal. 